\title{
Relationship between bacteria, phytoplankton and heterotrophic nanoflagellates along the trophic gradient
}

\author{
N. Krstulović*, M. Šolić \& I. Marasović \\ Institute of Oceanography and Fisheries, P.O.Box 500, 21000 Split, Croatia
}

\begin{abstract}
Bacterial and heterotrophic nanoflagellates (HNF) abundance, as well as bacterial production and chlorophyll a levels, were measured at five sites extending from the coastal zone toward the open Adriatic in the penod from March to Octoher 1995. The investigiated areas were grouped into trophic categories according to concentrations of chlorophyll a. All the biotic-parameters increased along the trophic gradient, leading to eutrophy, but they did not increase at the same rate. The bacterial biomass : phytoplankton biomass (BB : chl a) ratio decreased from about 10 in the very oligotrophic ared to 0.8 at the eutrophic site. In contrast the bacterial abundance: HNF abundance ratio (B: HNF) increased from 1000 bacteria per 1 tlacgellate in the oligotrophic system to 1700 bacterld flagellate ' in the eutrophic ares. Lecreasing $B B$ : chl $a$ and increasing $B$ : HNF ratios along the trophic gradient might reflect the different structures of the? microbial food web. Relationships between bacterial abundance and production, and chl $a$ and H.VF showed that bacterial abundance along the trophic gradient was regulated by the interplay between nutrient supply and grazing pressure. But in the oligotrophic system, bacterial abundance was more closely related to bacterial production and chl a than in the eutrophic system, suggesting stronger control of bacterial abundance by substrate supply. On the other hand, the coupling between bacteria and HNF, and uncoupling befween bacterial abundance and production in the? eutrophic system, showed that the importance of bacternovory increased in richer systems.
\end{abstract}

\section{INTRODUCTION}

Many authors have shown that bacterial abundance changes with the trophic state in freshwater and marine systems (Azam et al., 1983; Fuhrman et al., 1980; Bird \& Kalft, 1984; Cho \& Azam, 1990; Gasol \& Vaque, 1993; Pace \& Cole, 1994). Within these systems, the trophic relationships are undoubtediy very complex and characterized by numerous feedbacks. There is considerable empirical evidence of resource control of bacteria (bottom-up control) and of grazing control of bacteria (top-down control) IGüde, 1986, 1989; Gasol, 1994). Large-scale comparative studies demonstrate strong correlations between bacterial abundance and bacterial productivity and between bacteria and chlorophyll, suggesting signiticant resource regulation of bacteria (Bird \& Kalff, 1984; Cole et al., 1988; Currie, 1990). On the other hand, comparisons of the quantities of heterotrophic nanoflagellates (HNF) and bacteria imply that, in some

\footnotetext{
- Addressee for all correspondence.
} 
cases, predatory control (top-down regulation) of bacteria may be of major importance in eutrophic environments (Berninger et al., 1991; Sanders et al., 1992).

One way to determine whether the regulation of bacteria is by top-down or bottomup control is to consider how bacterial abundance and growth rates change along a resource gradient. For this purpose, we evaluated the regulation of bacterial abundance by comparing the relationship between bacterial abundance and production, between bacteria and chl $a$, and between bacteria and HNF along a trophic gradient in the Adriatic sea.

\section{MATERIAL AND METHODS}

Samples for bacterial and HNF counts, chl $a$, and bacterial production were collected on a monthly basis from March to October 1995 at 5 stations (A-E) located between the coastal zone and the open Adriatic.

Samples for counting were poured into sterile, acid washed, glass bottles fixed with Formalin (final conc. $2 \%$ ) and processed in the laboratory within two days after collecting.

\section{Chlorophyll a (Chl a)}

Chlorophyll $a$ content was measured on a Turner 112 fluorometer after acetone extraction (Strickland \& Parsons, 1972).

\section{Bacterial and flagellate counts}

Enumeration of bacteria and heterotrophic nanoflagellates (HNF) were made by epifluorescence microscopy using the standard acridine orange direct counting technique (Hobbie et al., 1977) for bacteria, and proflavine staining technique, which enable a distinction between heterotrophic and autotrophic cells, for HNF (Haas, 1982). For biovolume estimates, length and width of bacterial and HNF cells were measured with an eyepiece graticule (New Portion (i12; Graticules, Ltd, UK). Biovolume was converted to carbon biomass, assuming $0.220 \mathrm{pg} \mathrm{C} \mu \mathrm{m}^{3}$ for bacteria (Bratbak \& Dundas, 1984) and HNF (Borsheim \& Bratbak, 1987).

\section{Bacterial production}

Bacterial cell production was measured with the ${ }^{3} \mathrm{H}$-thymidine incorporation technique (Fuhrman \& Azam, 1982). [Methyl- ${ }^{3} \mathrm{H}$ ] thymidine was added in 10-ml samples at a final concentration of $10 \mathrm{nM}$ (specific activity $86 \mathrm{Ci} \mathrm{mmol}^{-1}$; Amersham Ltd, UK). Triplicate samples and a Formalin killed adsorption control (final conc. $0.5 \%$ ) were incubated at in situ temperature in the dark for $1 \mathrm{~h}$ (linearity of thymidine uptake was previously checked). The incubations were stopped with Formalin (final conc. $0.5 \%$ ). To each $10-\mathrm{ml}$ sample and control, an equal volume of ice-cold $10 \%(\mathrm{wt} / \mathrm{vol}) \mathrm{TCA}$ was added, and the mixtures were kept on ice for $15 \mathrm{~min}$. The TCA-insoluble fraction was collected by filtering the sample through a $25-\mathrm{mm}, 0.2 \mu \mathrm{m}$ pore size, cellulose nitrate filter. The filters were rinsed five times with $1 \mathrm{ml}$ of ice-cold $5 \%(\mathrm{wt} / \mathrm{vol})$ TCA. The fil- 
ters were dried, placed in scintillation vials, dissolved in 10-ml Filter-count ${ }^{\top \mathrm{M}}$ (Packard scintillation cocktail), and counted after $24 \mathrm{~h}$ storage in a scintillation counter (Packard Tricarb 2500 TR). The conversion factors to estimate bacterial cell production were calculated from bacterial cell numbers and ${ }^{3} \mathrm{H}$-thymidine incorporations in the $<1 \mu \mathrm{m}$ size fractions (Riemann et al., 1987) as: $C F=\left(N_{2}-N_{1}\right) /{ }^{3} \mathrm{H}_{1 \mathrm{~m}}$, where $\mathrm{N}_{\text {: }}$ and $\mathrm{N}_{2}$ are the numbers at the beginning and at the end of the experiment; ${ }^{3} \mathrm{H}_{\text {:nc }}$ is the integrated ${ }^{3} \mathrm{H}$-thymidine incorporation rate during the experiment.

\section{RESULTS AND DISCUSSION}

\section{Trophic system}

The investigated areas were grouped into trophic categories according to concentrations of chl $a$ and were arranged by increasing chl $a$ concentrations (Fig. 1).

$\mathrm{Chl}$ a concentrations in the oligotrophic area ( $E$ site) ranged from 0.04 to $0.57 \mathrm{mg}$ $\mathrm{m}^{3}$ with a mean value of $0.126 \pm 0.015 \mathrm{mg} \mathrm{m}^{3}$ (SE), in the eutrophic area (A site) from 0.16 to $18.36 \mathrm{mg} \mathrm{m}^{-3}$ with a mean value of $4.8 \pm 1.14 \mathrm{mg} \mathrm{m}^{3}$. Ratio of the average $\mathrm{chl} a$ concentrations in the oligotrophic system to that in the eutrophic area was $1: 38$. In the mesotrophic area $(B, C, D$ sites) chl a concentrations averaged $0.239 \pm 0.04 \mathrm{mg}$ $\mathrm{m}^{3}, 0.572 \pm 0.071 \mathrm{mg} \mathrm{m}^{-3}$, and $0.613 \pm 0.51 \mathrm{mg} \mathrm{m}^{-3}$ at sites $\mathrm{B}, \mathrm{C}$, and $\mathrm{D}$, respectively (Fig. 1).

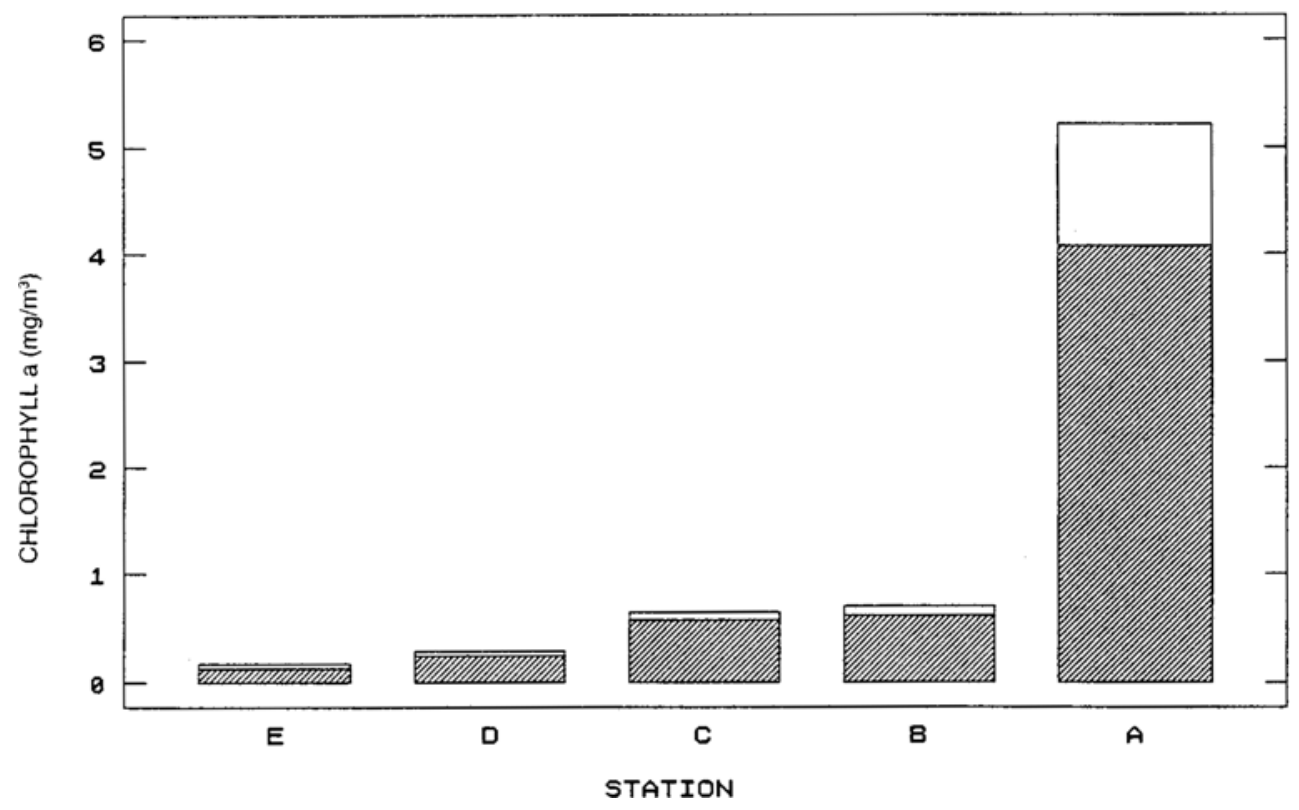

Fig. 1. Average concentrations of chl $a$ at the investigated sites (white ared of bar indicates $1 \mathrm{SE}$ ) 


\section{Bacterial and HNF abundances}

Abundances of bacteria and HNF showed similar patterns along the trophic gradient as shown by chl a concentrations. In the oligotrophic system, bacterial abundances ranged from $0.41 \times 10^{\text {h }}$ to $3.43 \times 10^{\text {h }}$ cells $\mathrm{ml}^{-1}$ with a mean value of $0.88 \pm 0.06 \times 10^{6}$ cells $\mathrm{ml}^{-1}$, equivalent to a biomass value of $16.65 \mu \mathrm{g} \mathrm{Cl} \mathrm{l}^{1}$. In the eutrophic site, abundances ranged from $1.09 \times 10^{6}$ to $12.83 \times 10^{\text {h }}$ cells $\mathrm{ml}^{-1}$ with a mean value of $3.88 \pm 0.61 \times 10^{\text {ti }}$ cells $\mathrm{ml}^{-1}\left(81.09 \mathrm{\mu g} \mathrm{C}^{-1}\right)$. In mesotrophic waters, bacterial abundance was fairly uniform at all investigated sites and averaged $1.73 \pm 0.21 \times 10^{6}$ cells $\mathrm{ml}^{\prime}$ at $\mathrm{D}$ site, $1.79 \pm 0.19 \times 10^{6}$ cells $\mathrm{ml}^{-1}$ at $\mathrm{C}$ site and $1.96 \pm 0.15 \times 10^{\mathrm{n}}$ cells $\mathrm{ml}^{-1}$ at B site (Fig. 2a). The ratio of bacterial abundance in the oligotrophic system to those in the mesotrophic and eutrophic systems was $1: 2: 4$.

Similarly, the lowest abundances of HNF were measured in the oligotrophic waters, where counts ranged from $0.48 \times 10^{3}$ to $1.69 \times 10^{3} \mathrm{ml}{ }^{1}$, with a mean value of $1.05 \pm$ $0.5 \times 10^{3} \mathrm{ml}^{-1}$. In the eutrophic waters, HNF abundance varied from $0.29 \times 10^{3}$ to $8.76 \times 10^{3}$ $\mathrm{ml}^{-1}$ and averaged $2.64 \pm 0.43 \times 10^{3} \mathrm{ml}^{-1}$. In the mesotrophic area, HNF abundance averaged $1.47 \pm 0.11 \times 10^{3} \mathrm{ml}^{-1}$ at $\mathrm{D}$ site, $1.99 \pm 0.21 \times 10^{3} \mathrm{ml}^{1}$ at $\mathrm{C}$ site, and $2.00 \pm 0.19 \times 10^{3}$ $\mathrm{ml}^{\prime}$ at site B (Fig. 2b). It is apparent that HNF numbers increased with increasing trophic levels. However, the ratio of HNF abundance in the oligotrophic system to that in the eutrophic $(1: 2.5)$ was lower than that of bacteria.

\section{Bacterial production}

Bacterial production values along the trophic gradient increased far more than the bacterial abundance levels. In the oligotrophic area production ranged from 0.43 to $55.2 \mu \mathrm{g} \mathrm{C} \mathrm{l}^{-1}$ day ' with a mean value of $17.19 \pm 1.99 \mu \mathrm{g} \mathrm{Cl}^{-1}$ day '. In the eutrophic area, bacterial production ranged from 0.3 to $2179 \mu \mathrm{g} \mathrm{C} \mathrm{I}$ ' day ' and averaged $367.66 \pm$ $120.13 \mu \mathrm{g} \mathrm{Cl}^{1}$ day ${ }^{\prime}$ (Fig. 3a). Bacterial production in the eutrophic system was 21 -fold higher than that of the oligotrophic system. In the mesotrophic waters relatively low production values were recorded at the $D$ site (averaged $17.3 \pm 2.0 \mu \mathrm{g} \mathrm{Cl}^{\prime} \mathrm{day}^{-1}$ ) compared with those at sites $\mathrm{C}$ and $\mathrm{B}$ (averaged 43.39 $\pm 10.57 \mu \mathrm{g} \mathrm{C} \mathrm{l}{ }^{1} \mathrm{day}^{-1}$ and $45.1 \pm$ $\left.8.6 \mu \mathrm{g} \mathrm{Cl}^{:} \mathrm{day}^{-1}\right)$. This could be explained by the location of site $\mathrm{D}$. It is located at the entrance to Kaštela Bay where the specific water exchange structures were reflected in the distribution of bacteria and phytoplankton composition. Gačić et al. (1987) found a strong variation in bacterial abundances in the short period of one week, depending on the speed and the direction of current.

\section{Relationship between bacterial abundance and productivity}

Bacterial abundance was fairly well correlated with bacterial productivity. Thus, $55 \%$ of the bacterial abundance variation across the trophic gradient can be explained by variability in rates of production (Table 1), supporting the hypothesis of resource regulation of bacteria (bottom-up). Billen et al. (1990) argued that the relationship between bacterial production and abundance could be used to evaluate bottom-up and top-down regulation. Since bacterial resources are difficult to measure and are always at low concentrations, bacterial production serves as a surrogate measure of resources. Variability in rates of production reflect variability in resource inputs. Regressions of biomass as a 

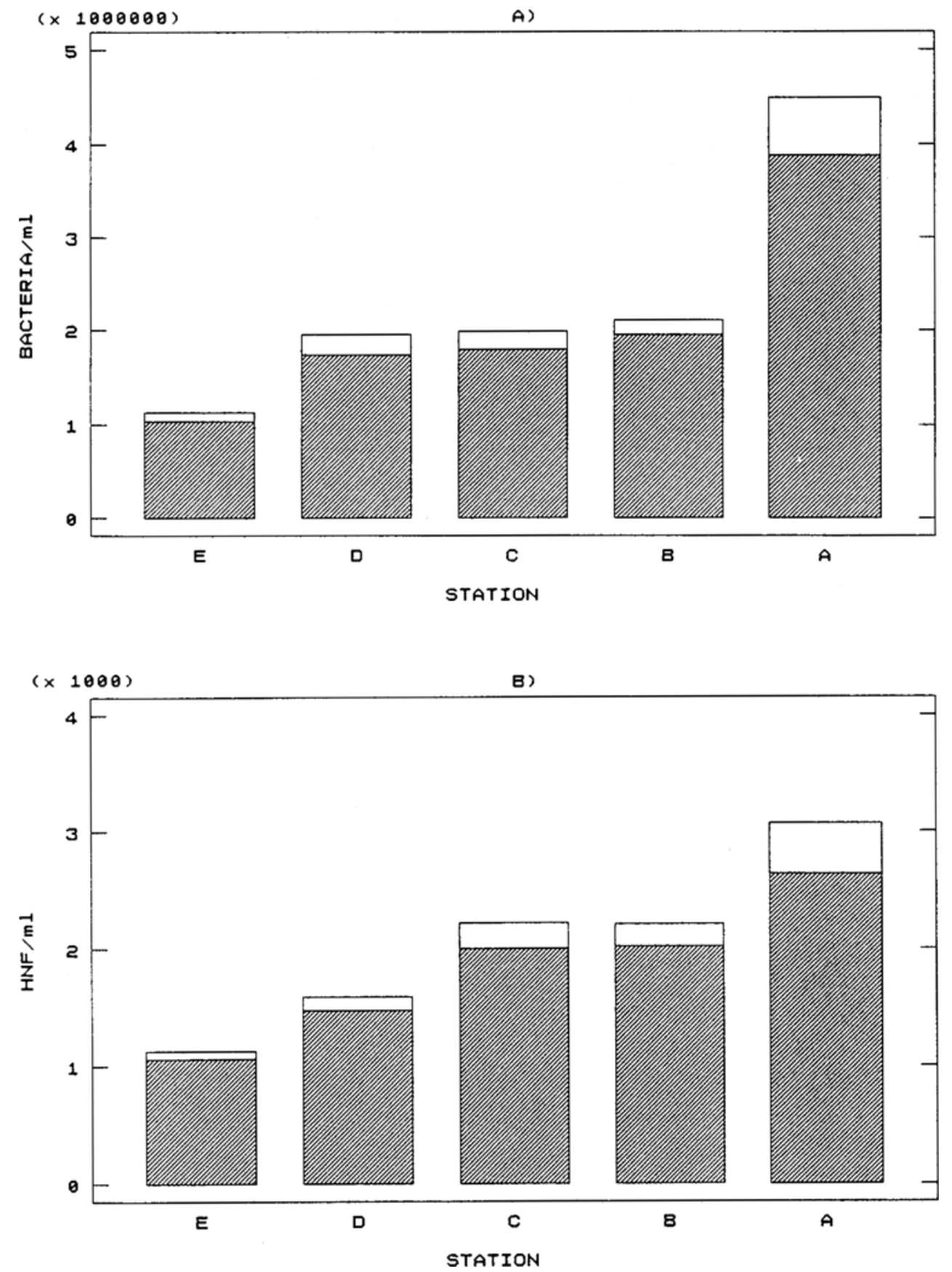

Fig. 2. Average abundances of bacterla (A) and HNF (B) at investigated sites arranged by increasing chl $a$ concentration (white bar indicates $1 \mathrm{SE}$ ) 

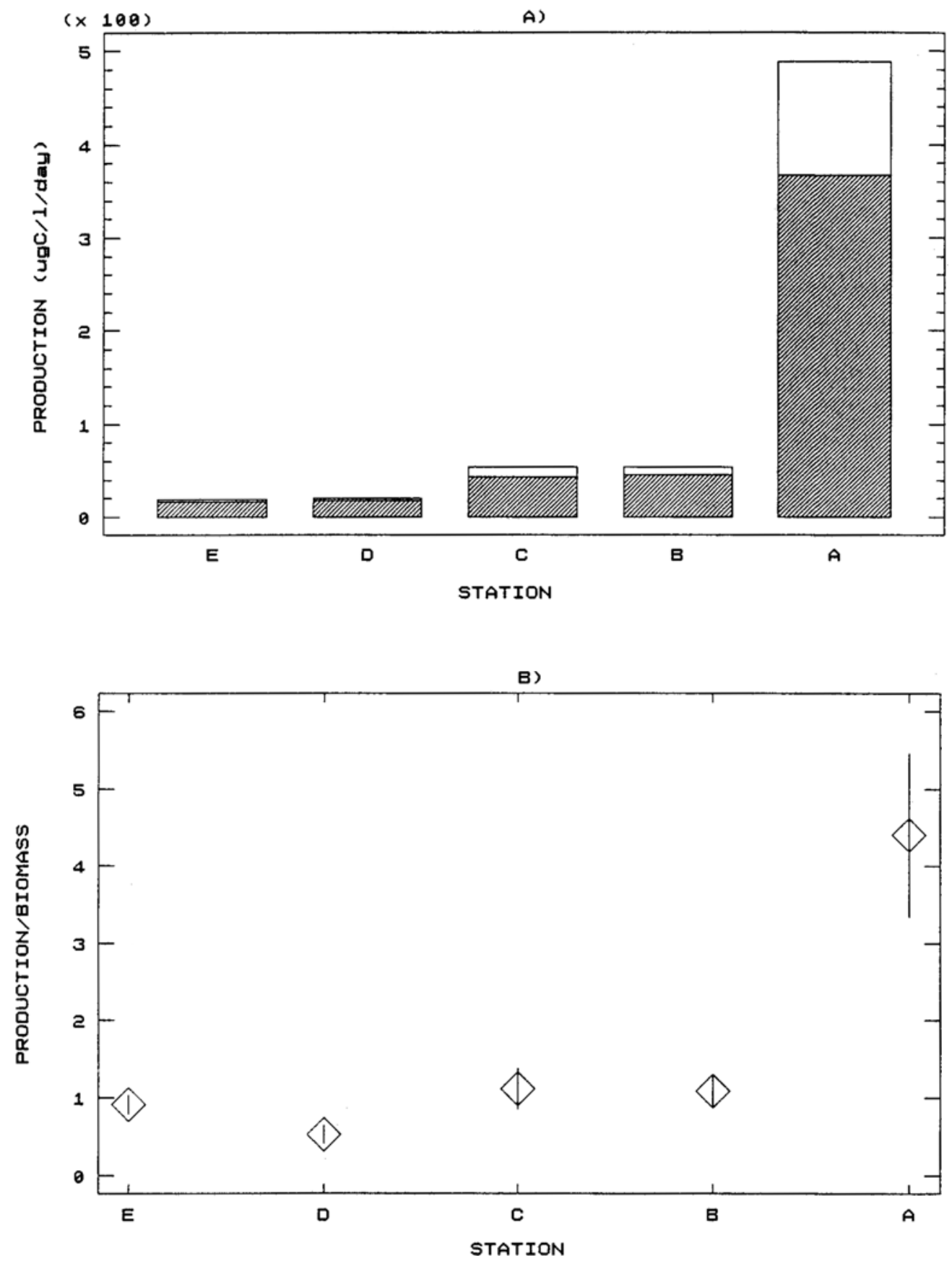

Fig. 3. Average bacterial production (white bar indicates $1 \mathrm{SE}$ ) (A) and P/B ratio (Error bars represent \pm 1 SE) $(B)$ at investigated sites arranged by increasing chl a concentration 
Table 1. Correlations between bacteria and all investigated parameters

\begin{tabular}{|c|c|c|c|}
\hline Parameter & $\mathrm{n}$ & $\mathrm{R}^{2}$ & $\mathrm{P}$ \\
\hline \multicolumn{4}{|l|}{ - Along trophic gradient } \\
\hline $\mathrm{Chla}$ & 35 & 0.36 & $<0.0001$ \\
\hline $\mathrm{HNF}$ & 35 & 0.45 & $<0.0005$ \\
\hline BP (Bdcterial production) & 35 & 0.55 & $<0.0001$ \\
\hline \multicolumn{4}{|l|}{ - Oligotrophic system } \\
\hline $\mathrm{Chla}$ & 7 & 0.94 & $<0.0005$ \\
\hline HNF & 7 & 0.07 & n.s. \\
\hline $\mathrm{BP}$ & 7 & 0.58 & $<0.05$ \\
\hline \multicolumn{4}{|l|}{ - Eutrophic system } \\
\hline $\operatorname{ct!} a$ & 7 & 0.05 & n.s. \\
\hline HNF & 7 & 0.64 & $<0.05$ \\
\hline $\mathrm{BP}$ & 7 & 0.42 & n.s. \\
\hline
\end{tabular}

function of production should have a steep slope if biomass is strongly determined by resources. Alternatively, there should be no reldtionship, or at best a shallow slope, between biomass and productivity if other factors such as mortality are most important in regulating bacterid. A complication not considered by Billen et al. (1990) is the situation where predation on bacteria is a major mechanism of resource recycling. In this case, increases :n mortality might lead to resource regeneration by consumers, resulting in bacterial biomass being partially or completely uncoupled from increases in bacterial productivity (Pace \& Cole, 1994). Comparing the relation of bacterial abundance to productivity for oligotrophic and eutrophic systems separately, we obtained results which could support the hypothesis of Pace \& Cole (1994). A significant positive correlation between bacterial abundance and productivity in the oligotrophic environments was found $\left(\mathrm{R}^{2}=0.58 ; \mathrm{n}=7 ; \mathrm{P}<0.05\right)$, but contrary to that, uncoupling between bacteria and productivity was recorded in the eutrophic waters (Table 1), suggesting that other factors such as mortality are most important in regulating abundance of bacteria. This was confirmed by comparing the production/biomass $(\mathrm{P} / \mathrm{B})$ ratios, which increased from the oligotrophic system where it was $0.9 \pm 0.11$, to the eutrophic system where $\mathrm{P} / \mathrm{B}$ ratio was $4.4 \pm 1.1$ (Fig. 3 b). This may occur if bacteria are more heavily grazed on in eutrophic: than in oligotrophic systems (Bird \& Kalff, 1984).

\section{Relationship between bacteria and chlorophyll a}

Bacterial and algal abundance increased along the trophic gradient, but it should be noted that algal abundance increased more rapidly than bacterial abundance did. Thus, a 38-fold increase in the chl a level was accompanied by only a 4 -fold increase in bacterial abundance. The coefficient of determination, which measures the degree of association between bacteria and phytoplankton ( $\mathrm{chl} a$ ) along a trophic gradient, was $\mathrm{R}^{2}=0.36(\mathrm{p}<0.001 ; \mathrm{n}=35)$. That is, $36 \%$ of the variability in bacterial abundance can be explained by the concentration of chl $a$. However, in the oligotrophic system bacte- 

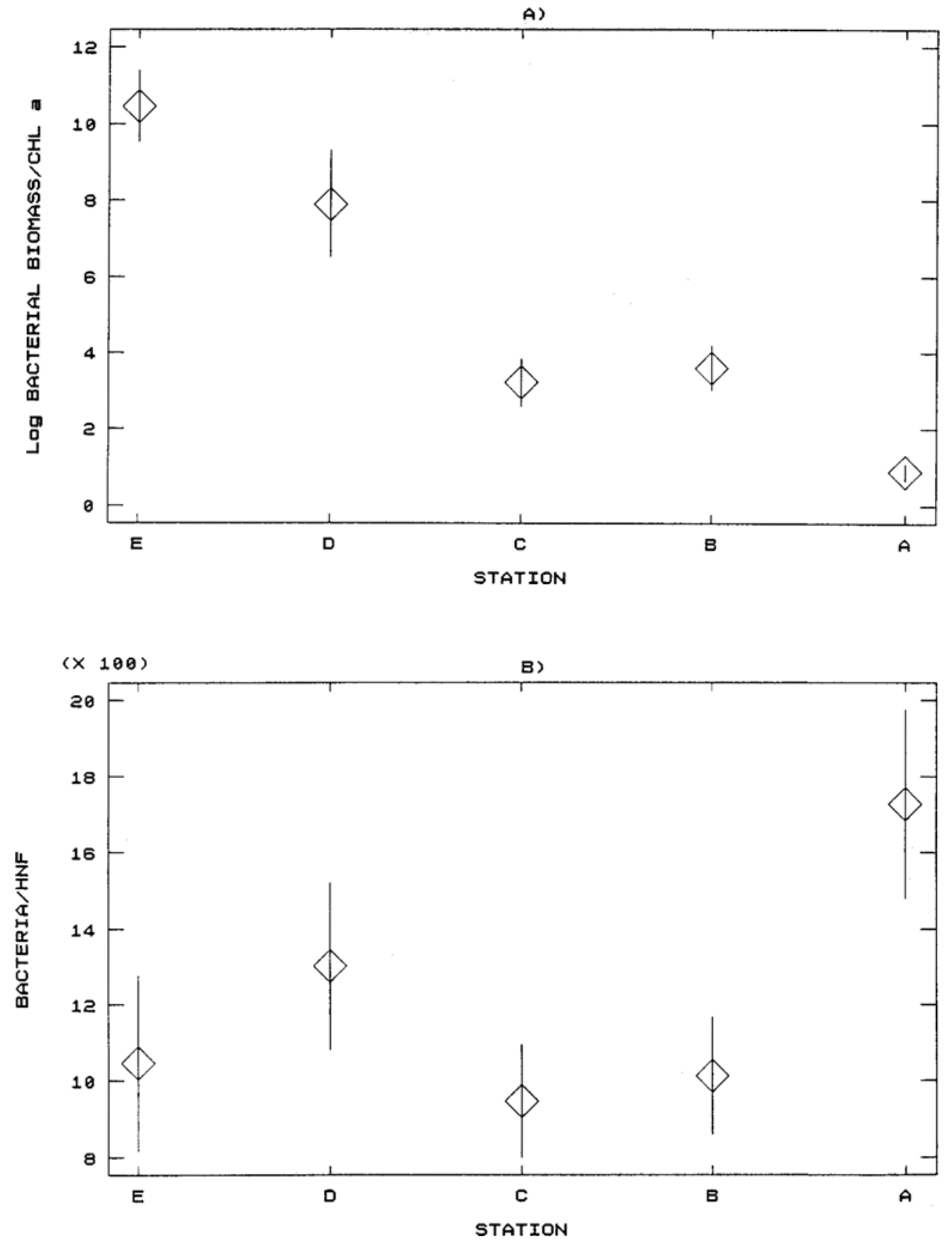

Fig. 4. B/chl $a(A)$ and $B / H N F(B)$ ratios at investigated sites arranged by increasing chl $a$ (Error bars represent $\pm 1 \mathrm{SE}$ ) 
rial abundance was much more closely related to phytoplankton $\left(R^{2}=0.94 ; p<0.001\right.$; $\mathrm{n}=7$ ), than in the eutrophic system, where $\mathrm{R}^{2}$ was not statistically significant (Table 1).

The $\mathrm{BB} / \mathrm{chl} a$ ratio also changed with trophic status. The ratio was extremely high in the oligotrophic system $(10.5 \pm 0.94)$ and decreased gradually toward the eutrophic site where the $\mathrm{BB} / \mathrm{chl} a$ ratio was only $0.8 \pm 0.21$ (Fig. $4 \mathrm{a}$ ). A very high $\mathrm{BB} / \mathrm{chl}$ a ratio was recorded in the samples containing $<0.24 \mu \mathrm{g} \mathrm{chl} a \mathrm{~m}^{-3}$ (sites $\mathrm{E}$ and $\mathrm{D}$; only eutrophic samples containing $>3 \mathrm{mg} \mathrm{chl} a$ had a $\mathrm{BB} / \mathrm{chl} a$ ratio less than 1 (site A). A striking result from this study is that in oligotrophic waters bacterial biomass exceeded phytoplankton biomass. We do not know what mechanisms are responsible for maintaining bacterial abundance at relatively high levels, even in highly oligotrophic waters. This may be due to changes in the way algae and bacteria compete for nutrients in waters of differing trophic status. Currie (1990) proposed that in very oligotrophic systems both bacterial and algal growth is $\mathrm{P}$ limited. Because bacteria are better competitors when orthophosphate is very scarce, bacteria obtain a larger share of the $P$, and increase in abundance relatively more rapidly than do algae. In richer systems, bacterial growth becomes simultaneously $P$ and $C$ limited. Algae then obtain greater portions of $P$, and algal abundance begins to increase more rapidly than bacterial abundance. Alternatively, it is possible that bacteria were more heavily grazed on in eutrophic than in oligotrophic systems (Beaver \& Crisman, 1982; Sanders et al., 1992). Dortch \& Packard (1989), as well, pointed out that the food webs in oligotrophic. and eutrophic waters must be fundamentally different. Their conclusion is based on the observation that the protein/chl a ratio (a rough measure of the dominance of the heterotrophic biomass over the photoautotrophic biomass) is very high in oligotrophic waters and gradually decreases to low values, as the chl $a$ values increase in eutrophic waters. They introduced the notion that the food webs in oligotrophic waters can be represented by an inverted pyramid with the heterotrophic biomass dominating the photoautotrophic biomass. Our results on the variation of $\mathrm{BB} / \mathrm{chl} a$ are consistent with the idea of Dortch \& Packard (1989) and Cho \& Azam (1990), and further enlarge on their notion by showing that the dominance of heterotrophic biomass in oligotrophic waters could be explained by the persistence of high bacterial biomass. Whatever the mechanism, an important consequence of the phenomenon is that in oligotrophic waters, bacterial biomass was dominant over phytoplankton biomass, and the opposite is true for eutrophic waters, which may reflect a fundamentally different organization of foodwebs in the oligotrophic and eutrophic waters.

\section{Relationship between bacteria and HNF}

By studying the relation between bacterial and HNF abundance along the trophic gradient, a positive correlation was found. The coefficient of determination $\left(\mathrm{R}^{2}\right)$ was $0.44(\mathrm{p}<0.001 ; \mathrm{n}=35)$, which means that $44 \%$ variation of bacterial abundance could be explained by the variability in HNF abundance, or by predator-prey dependence. This dependence is even stronger in very eutrophic waters, explaining $64 \%$ of the variability in bacterial abundance (Table 1). However, quite opposing data on bacteriaHNF dependence can be found in the literature. The results of Gasol \& Vaque (1993) showed a weaker relationship between bacteria and H.NF across a wide diversity of 
systems $\left(R^{2}<0.25, p<0.01\right)$ than we found, suggesting that organisms other than HNF are important predators on bacteria in various environments and/or other loss processes could be more important than predation. Contrary to these results, Sanders et al. (1992) and Berninger et al. (1991) suggested that a close coupling between bacteria and HNF should be expected in systems with different trophic levels, implying that bacterial production and HNF grazing were also closely related.

The $\mathrm{B} / \mathrm{HNF}$ abundance ratio, which could be used as an index of grazing pressure, showed that bacterial abundance in relation to HNF abundance increased from the oligotrophic system where the ratio was 1046:1 to the eutrophic system where 1722 bacteria were present for every flagellate (Fig. 4 b). Nevertheless, there was no proportional increases in HNF with respect to bacteria, suggesting that relationships between bacteria and flagellates may not be as widespread as suggested by Sanders et al. (1992). They found this ratio was constant at about 1000:1 across a wide variety of ecosystems, and they examined the implications of this ratio by developing a model of bacterial dynamics as a function of substrate supply and flagellate predation. To maintain a constant 1000:1 ratio of flagellates to bacteria, regulation must shift across resource gradients dccording to their model. In oligotrophic environments, substrate supply controls bacterial abundance, but grazing by HNF reduces bacteria below carrying capacity in more eutrophic systems. Thus, our finding of increasing $B / H I N F$ ratio along trophic systems suggests that in more productive areas, such as site $A$ in our study, the heterotrophic nanoplanktonic protozoa do not immediately reduce bacteria as much as might be expected because grazing microzooplankton quickly respond to an increase in the number of HNF available (Giasol \& Vaque, 1993).

\section{CONCLUSION}

All investigated parameters increased along the trophic gradient, but they did not increase at the same rate. Differing rates of increase in individual parameters caused decreasing $\mathrm{B} / \mathrm{chl} a$ and increasing $\mathrm{B} / \mathrm{HNF}$ ratios with increasing trophic levels which may reflect the different structures of the microbial food web.

Statistically significant positive correlations between bacterial abundance and individual variables, such as bacterial productivity, chl $a$, and HNF along the trophic gradient suggest that bacterial abundance is determined by the interplay between nutrient supply and grazing pressure. But, in the oligotrophic ecosystem we ascertained that bacterial population was much more closely related to bacterial productivity and $\mathrm{chl} a$, suggesting stronger control of bacterial abundance by substrate supply. On the other hand, the coupling between bacteria and HNF and uncoupling between bacterial abundance and productivity in the eutrophic system, showed that the importance of bacteriovory increased in richer systems.

\section{LITERATURE CITED}

Azam, F., Fenchel, T., Field, K. G., Gray. K. S., Meyer-Reil, L. A. \& Thigstad, F., 1983. The ecological role of water-column micrubes in the sea. - Mar. Ecol. Prog. Ser. 10, 257-263.

Beaver, J. R. \& Crisman, T. L., 1982. The trophic response of ciliated protozoans in freshwater lakes. - Limnol. Oceanog̣r. 27, 246-253. 
Berninger. U.-G., Finlay, B. J. \& Kuuppo-Leinikki, P., 1991. Protozoan control of bacterial abundances in freshwater - Limnol Oceanogr. 36, 139-147.

Billen, G., Servais, P. \& Becquevort, S., 1990. Dynamics of bacterioplankton in oligotrophic and cutrophic aquatic environments: bottom-up or top-down control? - Hyclobiologia 207, 37-42.

Bird, D. F. \& Kalff, J., 1984. Empirical relationship between bacterial abundance and chlorophyll concentration in fresh and marine waters. - Can. J. Fish. Aquat. Sci. 41.1015-1023.

Borsheim, K. Y. \& Bratbak, G., 1987. Cell volume to cell carbon conversion factors for a bacteriovorous Monas sp. enriched from sedwater. - Mar. Ecol. Prog. Ser. 36, 171-175.

Bratbak, G. \& Dundas, I., 1984. Bacterial dry matter content and biomass estimations. - Appl. environ. Microbiol. 48,755-757.

Cho, B. C. \& Azam, F., 1990. Biogeochemical significance of bacterial biomass in the ocean's euphotic zone. - Mar. Ecol. Prog. Ser. 63, 253-259.

Cole, J. J., Findlay, S. \& Pace. M. L.. 1988. Bacterial production in fresh and saltwater ecosystems a cross-system overview. - Mar. Ecol. Prog. Ser. 43, 1-10.

Currie, D. J., 1990. Large-scale variability and interactions among phytoplankton, bacterioplankton, and phosphorus. - Limnol. Oceanogr. 35, 1437-1455.

Dortch, Q. \& Packard, T., 1989. Differences in biomass structure between oligotrophic and eutrophic marine ecosysterns. - Deep Sea Res. 36. 223-240.

Fuhrman, J. A. Ammerman, J. W. \& Azam, F. 1980. Bacterloplankton in the coastal euphotic zone: distribution, dctivity and possible relationship with phytoplankton. - Mar. Biol. 60, 201-207.

Fuhrman, J. A. \& Azam, F., 1982. Thymidine incorporation as a measure of heterotrophic bacterioplankton production in marine surface waters: evaluation and field results. - Mar. Biol. 66, $109-120$.

Gacic, M., Dadic, V., Krstulović, N., Marasovic, I., Morovic, M., Pucher-Petkovic, T. \& Sviličic, N., 1987. Nedr-shore transport process induced by the wind. - Estuar. coast. Shelf Sci. 24, 35-46.

Gasol, J. M., 1994. A framework for the assessment of lop-down vs bottom-up control of heterotrophic nanoflagellate abundance - Mar. Ecol. Prog. Ser. 113, 291 -300

Ciasol, J. M. \& Vaque, D. 1993. Lack of coupling between heterotrophic nanofiagellates and bacterid: A general phenomenon across aquatic systems? - Limnol. Oceanogr. 38. 6.57-66.5.

Gucie, H., 1986. Loss processes influencing the growth of planktonic bacterial population in Lake Constanct. - J. Plankt. Res. 8. 795-810.

Giide, H., 1989. The role of grazing on bacterid in plankton succession. In: Plankton ecology. Ed. by Li Sommer Springer, New York, 337-364

Haas, L. W. 1982. Improved epitluorescence microscopy for observing planktonic micro-organisms. - Annls Inst. océanogr. 58, 261-266.

Hobbie. J. E., Daley, R. J. \& Jasper, S., 1977. Use of Nucleopore filters for counting bacteria by fluorescence microscopy. - Appl environ. Microbiol. 33, 122.5-1228.

Pace, M. L. \& Cole, J. J., 1994. Comparative and expermental approaches to top-down and bottom-up regulation of bacteria. - Microb. Ecol. 28, 181-193.

Riemann, B., Bjorsen, P. K., Vewell, S. \& Fallon, R., 1987. Calculation of cell production of coastal marine bacteria based on measured incorporation of ("H)thymidine. - Limnol. Oceanogr. 32. $471-476$

Sanders, R. W., Caron, D. A. \& Berninger, U. (i., 1992. Relationships between bacteria and heterotrophic nanoplankton in marine and fresh waters: an inter-ecosystem comparison. - Mar. Ecol. Prog. Ser 86, 1-14.

Strickland, J. D. I1. \& Parsons, T. R., 1972. A practical handbook of seawater analysis. - Bull. Fish. Res. Bd Can 167, 1 -310 